\title{
Factors associated with involuntary hospital admissions in technology-dependent children
}

\author{
Fatores associados às internações não eletivas em crianças dependentes de tecnologia \\ Factores asociados con las hospitalizaciones no electivas en niños dependientes de tecnología
}

\author{
Aline Cristiane Cavicchioli Okido' ${ }^{1}$, Juliana Coelho Pina², Regina Aparecida Garcia Lima ${ }^{3}$
}

How to cite this article:

Okido ACC, Pina JC, Lima RAG. Factors associated with involuntary hospital admissions in technology-dependent children. Rev Esc Enferm USP. 2016;50(1):29-35. DOI: http://dx.doi.org/10.1590/S0080-623420160000100004

${ }^{1}$ Universidade de São Paulo, Escola de Enfermagem de Ribeirão Preto, SP, Brazil.

${ }^{2}$ Universidade Federal de Santa Catarina, Departamento de Enfermagem, Florianópolis, SC, Brazil.

${ }^{3}$ Universidade de São Paulo, Escola de Enfermagem de Ribeirão Preto, Departamento de Enfermagem Materno Infantil e Saúde Pública, Ribeirão Preto, SP, Brazil.

\begin{abstract}
Objective: To identify the factors associated with involuntary hospital admissions of technology-dependent children, in the municipality of Ribeirão Preto, São Paulo State, Brazil. Method: A cross-sectional study, with a quantitative approach. After an active search, 124 children who qualified under the inclusion criteria, that is to say, children from birth to age 12, were identified. Data was collected in home visits to mothers or the people responsible for the children, through the application of a questionnaire. Analysis of the data followed the assumptions of the Generalized Linear Models technique. Results: 102 technology-dependent children aged between 6 months and 12 years participated in the study, of whom $57 \%$ were male. The average number of involuntary hospital admissions in the previous year among the children studied was 0.71 $( \pm 1.29)$. In the final model the following variables were significantly associated with the outcome: age $(\mathrm{OR}=0.991$; $\mathrm{CI} 95 \%=0.985-0.997)$, and the number of devices $(\mathrm{OR}=0.387$; $\mathrm{CI} 95 \%=0.219-0.684)$, which were characterized as factors of protection and quantity of medications $(\mathrm{OR}=1.532$; $\mathrm{CI} 95 \%=1.297-1.810)$, representing a risk factor for involuntary hospital admissions in technology-dependent children. Conclusion: The results constitute input data for consideration of the process of care for technology-dependent children by supplying an explanatory model for involuntary hospital admissions for this client group.
\end{abstract}

DESCRIPTORS

Child; Hospitalization; Pediatric Nursing. 


\section{INTRODUCTION}

Technology-dependent children are conceived of as being those who need some device to compensate for the loss of a vital function, such as mechanical breathing machines, peritoneal dialysis, and/or use of gastrostomy, tracheostomy, or other processes. Innumerable clinical conditions can result in the use of these technical devices, for example, cerebral palsy, myelomeningocele, genetic syndromes, congenital deformities, and others ${ }^{(1)}$.

Technology-dependent children are in the group of children with special health needs (CSHN), since they have damaged health, and need continuous attention from family members and health professionals, in excess of the care that is necessary for other children of the same age group ${ }^{(2)}$. In the literature, there are several co-existent denominations for referring to these children, such as medically fragile children - referring to those that have serious health problems and frequently need technological devices to maintain their vital functions ${ }^{(3)}$, and children with medical complexity $(C M C)$ - those that have multi-systemic disorders of a congenital or acquired nature, require intensive care and may be dependent on technological devices ${ }^{(4)}$.

It is estimated that $15 \%$ to $20 \%$ of children in the United States up to the age of 17 have some special health need $^{(5)}$. A study that aimed to estimate the number of medically fragile children, and the cost of their health services, showed that $0.25 \%$ of the children of the US State of North Carolina fitted this definition. The study also indicated that, although they represent a small portion, they were responsible for the greater part of the expenditure on the health services $^{(3)}$. The high cost may be the result of accompaniment by specialists, frequent surgery, and attention given by tertiary care services ${ }^{(4)}$. In relation to Brazil, there is no estimate of the number of CSHN, but only isolated records of incidence in certain locations, of which the most significant have been studies in Rio de Janeiro, in the state of Rio de Janeiro, and Santa Maria, is the state of Rio Grande do Sul ${ }^{(6)}$.

As a result of their fragile state of health, these children need frequent admissions to hospital ${ }^{(7)}$. However, researchers suggest that the fragile state of some clinical services, associated with prolonged hospital admissions and aggressive treatments, frequently worsens the child's state of health ${ }^{(8)}$. On similar lines, a US study indicates that frequent and prolonged hospital admissions may worsen the clinical condition and generate new demands for technological devices ${ }^{(9)}$. As well as the biological dimension, frequent hospital admissions of a son or daughter can give rise to a series of family misadjustments, such as maternal overload, financial difficulties, and sadness of the healthy siblings ${ }^{(10)}$.

In view of the above, the need for this investigation is shown by the need for knowledge of the elements that contribute to prevention of hospital admissions in this population. Thus, the study aims to identify the factors associated with involuntary hospital admission among technologydependent children, in the municipality of Ribeirão Preto, São Paulo State.

\section{METHOD}

This is a cross-sectional study with quantitative approach. Investigation was carried out in the municipality of Ribeirão Preto, in the northeastern region of the state of São Paulo, Brazil.

The participants were identified through an active search, since the information relating to this group of children was not systematized in the health units. The active search took place in the health services of the Municipal Health Department, in the institutions for support for CSHN registered with the Municipal Councils for the Rights of Children and Adolescents, and in two private health institutions that provided home care, of which one refused to participate. It also benefitted from referred informants: when contact was made with one family, the investigators enquired whether they knew of other children with the same condition.

After active search, 124 children were identified as qualifying with the criteria, that is to say, aged up to 12 , dependent on some technological device for maintenance of life, and resident in the municipality of Ribeirão Preto, São Paulo State. Of these, 102 technology-dependent children took part in the study, since upon contacting the families it was found that 20 children had ceased to use the technological device and three had died. Only one mother refused to take part in the survey. Home visits for collection of data were made in a single survey period, January through April 2011, with average duration of 30 minutes. We also note that five of these children lived in a philanthropic institution that provides 24 -hour multidisciplinary care to children with cerebral palsy.

The data collection instrument was organized with data identifying the child and questions related to the clinical and social-demographic conditions. The instrument was filled out using the reports of the mothers or guardians as source: hence they are self-reported data. The medical records were used only for filling out the instrument of the children that were institutionalized - a total of five.

In relation to the information on hospital admissions, the mothers or guardians stated the number of admissions in the prior year, and the reasons. Based on this information the hospital admissions were categorized into voluntary and involuntary. For this study, previously programmed hospital admissions were left out of account, that is to say, those that did not correspond to a worsening of the child's clinical condition, such as voluntary surgeries and admissions for periodic administration of medication. Similarly, a US study which aimed to analyze the association between outpatient accompaniment of children with medical complexity and re-hospitalizations within the first 30 days after hospital discharge also left planned admissions out of account ${ }^{(11)}$.

The number of involuntary admissions in the prior year (January 1 through December 31,2010) was considered as a dependent variable or a response variable, and classified as numerical.

The following were adopted as independent variables: the age of the child in months (numerical variable) the etiology of the child's health condition (category variable: acquired 
cause related to birth, congenital cause, acquired cause not related to birth, and one other cause); continuous use of medications (Yes/No), quantity of medications (numerical variable); use of technological device for feeding (Yes/No); use of technological device for evacuation (Yes/No); use of technological device for respiration (Yes/No); use of technological device for other purposes (Yes/No); number of devices (numerical variable); development activities such as physiotherapy, speech therapy, equine therapy (Yes/No); home care (Yes/No); and family income, in Reais (numerical variable).

The data were coded and posted in a formatted database in Excel, using double-input typing. The database was validated by a comparison of the two spreadsheets, using subtraction - after which any cells with non-zero values were checked, the original data collection instrument checked, and the due corrections made. After validation, the database was exported to the SPSS software, version 16.0, in which the analyses were carried out. The statistical tests were made by a statistician, after analysis of the empirical material. In the descriptive phase of the statistical analysis, participating children were characterized according to the variables of the study. For the category variables the measures of absolute and relative frequency were used, while for the description of the numerical variables the measures of central tendency, variability and position were used.

After descriptive analysis, a comparison was made of the averages of involuntary hospital admissions among the categories of the independent variables using the Mann-Whitney test for dichotomy variables and the Kruskal-Wallis for those with more than two categories. The Spearman correlation coefficient was also calculated for the numerical variables. For the tests, a significance level of $5 \%$ was adopted ${ }^{(12)}$.

Finally, a multiple regression analysis was made using the Nelder and Wedderburn Generalized Linear Models technique ${ }^{(13)}$. This technique consists of opening the range of options for the distribution of the response variable, permitting it to belong to the exponential family of distributions, making possible a greater flexibility for the functional relationship between the average of the response variable and the independent variables ${ }^{(13)}$. Since the response (or dependent) variable of the study is a count variable, it was assumed that it follows the Poisson distribution ${ }^{(12)}$.

The process of insertion and removal of the variables in the regression model was carried out in two stages. First, all the independent variables were inserted and a first selection was made by the process known as stepwise. The Wald test was used as a selection criterion, with those variables that presented $\mathrm{p}$ values less than 0.05 remaining in the model.
Then, the following variables were added to the model of the first phase: Family income and etiology of the child's health condition, for the purposes of control. The final model, thus, comprised the variables that had $\mathrm{p}$ values less than 0.05 for the Wald test, and the control variables. For the variables of the final model chosen, the average mean increase in the number of involuntary admissions was calculated.

The study was carried out in accordance with Brazilian and internal rules of ethics in surveys involving human beings, and was approved by the Research Ethics Committee (Protocol 405/2010).

\section{RESULTS}

102 technology-dependent children took part in the study, aged between six months and 12 years, of whom $57 \%$ were male.

The characterization of the participants is presented in Table 1 (by category of variables) and Table 2 (by numerical variables). The average family income was $R \$ 1,700.00$. Congenital conditions, such as craniofacial deformities, cardiopathies and genetic syndromes were found to be the principal causes of the need for use of technology, with a combination of more than one cause being frequent. The technological devices for feeding, such as nasal-gastric tubes and gastrostomies, were the technologies most frequently used, with the use of only one device being most common. On average, the children used approximately two medications, and the majority made continuous use of medication. Use of development activities such as physiotherapy and speech therapy were common among the participants, but the greater part of the children did not receive home care given by health professionals.

The average number of involuntary hospital admissions in the prior year, among the children studied, was $0.71( \pm 1.29)$; 67 children $(65.7 \%)$ were not admitted due to involuntary causes, 19 (18.6\%) were admitted once, and 16 (15.7\%) had between two and six involuntary admissions in the prior year.

Table 1 also shows the averages of involuntary hospital admissions among the children participating in the study, by exploratory category variables. The average of involuntary admissions was greatest among children who used some technological device for feeding ( 0.89 vs. $0.29, \mathrm{p}=0.028)$ or who carried out some development activity ( 0.81 vs. 0.47 , $\mathrm{p}=0.029$ ). In relation to the use of devices for other purposes, such as ventriculoperitoneal derivation, the average of involuntary admissions was greater among those who did not have them (0.77 vs. $0.00, \mathrm{p}=0.039)$.

Table 1 - Characterization of technology-dependent children by category variables - Ribeirão Preto, SP, Brazil, 2011.

\begin{tabular}{|c|c|c|c|c|c|c|}
\hline VARIABLES & 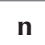 & $\%$ & Average of involuntary admissions & SD & Average $\mathbf{R}$ & $p$ \\
\hline Etiology of the child's health condition & & & & & & $0.238^{*}$ \\
\hline $\begin{array}{l}\text { Acquired causes related to birth } \\
\text { (neonatal hypoxia, premature births) }\end{array}$ & 15 & 14.7 & 0.87 & 1.457 & 54.70 & \\
\hline $\begin{array}{l}\text { Congenital causes } \\
\text { (craniofacial deformity, cardiopathies, genetic syndromes) }\end{array}$ & 43 & 42.2 & 0.44 & 0.983 & 46.50 & \\
\hline $\begin{array}{l}\text { Acquired external causes } \\
\text { (neoplasia, drowning, falls, dog bites) }\end{array}$ & 18 & 17.6 & 0.61 & 1.243 & 50.28 & \\
\hline
\end{tabular}




\begin{tabular}{|c|c|c|c|c|c|c|}
\hline VARIABLES & $\mathbf{n}$ & $\%$ & Average of involuntary admissions & SD & Average $\mathbf{R}$ & $p$ \\
\hline More than one cause & 26 & 25.5 & 1.12 & 1.608 & 58.77 & \\
\hline Continuous use of medications & & & & & & $0.126^{\dagger}$ \\
\hline Yes & 92 & 90.2 & 0.75 & 1.323 & 52.74 & \\
\hline No & 10 & 9.8 & 0.30 & 0.949 & 40.05 & \\
\hline $\begin{array}{l}\text { Use of technological device for feeding (gastrostomy, } \\
\text { nasogastric tube, jejunostomy) }\end{array}$ & & & & & & 0.028 \\
\hline Yes & 71 & 69.6 & 0.89 & 1.450 & 55.09 & \\
\hline No & 31 & 30.4 & 0.29 & 0.693 & 43.27 & \\
\hline $\begin{array}{l}\text { Use of technological device for evacuation (vesical } \\
\text { catheter, colostomy, ileostomy) }\end{array}$ & & & & & & $0.181^{\dagger}$ \\
\hline Yes & 29 & 28.4 & 0.52 & 1.271 & 46.26 & \\
\hline No & 73 & 71.6 & 0.78 & 1.304 & 53.58 & \\
\hline \multicolumn{7}{|l|}{$\begin{array}{l}\text { Use of technological device for respiration (tracheostomy, } \\
\text { nasal catheter, mechanical ventilator) }\end{array}$} \\
\hline Yes & 31 & 30.4 & 0.68 & 1.423 & 49.03 & $0.509^{\dagger}$ \\
\hline No & 71 & 69.6 & 0.72 & 1.244 & 52.58 & \\
\hline $\begin{array}{l}\text { Use of technological device for other purposes } \\
\text { (ventriculoperitoneal derivation) }\end{array}$ & & & & & & 0.039 \\
\hline Yes & 8 & 7.8 & 0 & 0 & 34.00 & \\
\hline No & 94 & 92.2 & 0.77 & 1.331 & 52.99 & \\
\hline $\begin{array}{l}\text { Development activities carried out (physiotherapy, speech } \\
\text { therapy, occupational therapy) }\end{array}$ & & & & & & 0.029 \\
\hline Yes & 72 & 70.6 & 0.81 & 1.285 & 54.97 & \\
\hline No & 30 & 29.4 & 0.47 & 1.306 & 43.17 & \\
\hline Home care provided & & & & & & $0.900^{+}$ \\
\hline Yes & 15 & 14.7 & 0.93 & 1.907 & 49.70 & \\
\hline No & 82 & 80.4 & 0.62 & 1.129 & 48.87 & \\
\hline Not applicable & 5 & 4.9 & - & - & & \\
\hline
\end{tabular}

* Kruskal Wallis test.

† Mann-Whitney test.

* Children institutionalized - not taken into account for carrying out of the tests.

Table 2 - Characterization of technology-dependent children, by numerical variables - Ribeirão Preto, SP, Brazil, 2011.

\begin{tabular}{lccccc}
\hline VARIABLES & Average & Standard deviation & Median & Minimum & Maximum \\
\hline Age (months) & 73.3 & 45.8 & 70.5 & 6.0 & 162.0 \\
Family income (Reais) & $1,699.19$ & $1,240.84$ & $1,400.00$ & 200.00 & $7,000.00$ \\
Quantity of drugs & 2.3 & 1.8 & 2.0 & 0.0 & 8.0 \\
Number of devices & 1.36 & 0.56 & 1.0 & 1.0 & 3.0 \\
\hline
\end{tabular}

The correlation matrix involving the numerical with the number of involuntary hospital admissions variables and the outcome is given in Table 3 . The $(0.30, p<0.01)$ and with the number of devices $(0.38$, quantity of drugs showed a weak positive correlation $p<0.01)$.

Table 3 - Spearman correlations between involuntary hospital admissions in technology-dependent children and the numerical variables - Ribeirão Preto, SP, Brazil, 2011.

\begin{tabular}{|c|c|c|c|c|c|}
\hline VARIABLES & Number of admissions & Family income & Age & Number of medications & Number of devices \\
\hline Number of admissions & 1.00 & -0.035 & -0.152 & $0.296^{*}$ & -0.077 \\
\hline Family income & & 1.00 & 0.019 & 0.049 & 0.169 \\
\hline Age & & & 1.00 & -0.172 & -0.052 \\
\hline Number of medications & & & & 1.00 & $0.381^{*}$ \\
\hline Number of devices & & & & & 1.00 \\
\hline
\end{tabular}

* Significant correlation $(\mathrm{p}<0.01)$. 
The results of the regression analysis are given in Table 4. Only the following variables were significant in the final model: age, number of medications and number of devices used. These variables did not lose statistical significance even after the addition to the model of the variables family income and etiology of the child's health condition. It is emphasized that the effect of each variable was adjusted for the effect of all the others of the final model, including family income and etiology of the child's health condition, which were not significant, but remained in the model for the purposes of adjustment.

Table 4 - Factors associated with involuntary hospital admissions of technology-dependent children - Ribeirão Preto, SP, Brazil, 2011.

\begin{tabular}{lcccc}
\hline VARIABLES & Coefficient & $\boldsymbol{p}^{*}$ & OR & CI95\% \\
\hline Age (months) & -0.009 & $\mathbf{0 . 0 0 5}$ & 0.991 & $0.985-0.997$ \\
Number of medications & 0.427 & $<\mathbf{0 . 0 0 1}$ & 1.532 & $1.297-1.810$ \\
Number of devices & -0.949 & $\mathbf{0 . 0 0 1}$ & 0.387 & $0.219-0.684$ \\
Family income (reais) & 0.0001 & 0.307 & 1.000 & $1.00-1.0003$ \\
Etiology of the child's health condition & & & 0.913 \\
Causes acquired related to birth & -0.091 & 0.802 & 0.566 & $0.446-1.866$ \\
Congenital causes & -0.569 & 0.070 & 1.112 & $0.306-1.048$ \\
External acquired causes & 0.106 & 0.784 & $0.522-2.370$ \\
\hline
\end{tabular}

Age and number of devices had negative association with average number of admissions, while quantity of drugs had positive association. For each additional month of age, the figures indicated a relative reduction of $0.9 \%(\mathrm{OR}=0.991)$ in average number of admissions; while for each drug that the child used the number of admissions increased by a relative average of $53.2 \%(\mathrm{OR}=1.532)$. Finally, for number of devices, for each additional device used by the child, there was a relative reduction of $61.3 \%(\mathrm{OR}=0.387)$ in the average number of admissions.

\section{DISCUSSION}

Based on the results we find that age and number of devices are characterized as protection factors, and quantity of drugs as a risk factor, for involuntary hospital admissions in technology-dependent children. From the figures, these factors appear to exercise their influence on the number of admissions even in the context of different economic conditions, and the different causes of the situation of dependence on technology, which confirms the strength of the association of these three factors (age, number of devices and quantity of drugs) with the event of interest.

A US study ${ }^{(14)}$, which aimed to identify the factors associated with hospital re-admission in the first 30 days after children had been discharged from treatment for pneumonia, presented results that corroborated the findings of this study. Children under one year old were more subject to hospital re-admissions than those in the one to four age group, reaffirming the protection factor role of increased age. The authors also pointed out that children with chronic conditions had a higher index of re-admissions compared to children who did not have chronic conditions. On this point, $20.4 \%$ of the children participating in the study, considered to have chronic conditions and dependent on some technological device, needed hospital admission within 30 days after being discharged from hospital treatment for pneumonia.

A survey to study the health conditions and use of hospital resources by children submitted to tracheotomy found that $11 \%$ of these children needed four or more admissions in the six months following the procedure. The importance of considering the child's clinical condition was emphasized, since normally children who require tracheotomy have other co-morbidities that justify the need for frequent hospital admissions, such as neurological damage or chronic lung disease. In this context, the rate of hospital re-admission increases as the degree of the child's other adverse clinical conditions increases ${ }^{(15)}$.

In counterpart, this present study found that the majority of technology-dependent children had not been to hospital for involuntary reasons in the prior twelve months. It also showed the important contribution of the use of the devices as a way of avoiding such hospital admissions: the scale of the effect was a reduction of more than $60 \%$ in the average number of admissions for each device used. This result is compatible with the professional experience of the investigators, since, in clinical practice, they observe that, in the majority of cases, episodes of frequent admissions diminish after procedures such as tracheostomy and gastrostomy, since they contribute to the clinical improvement of the child.

In this direction, a study that analyzed the occurrence of respiratory diseases before and after insertion of the gastrostomy in children with cerebral palsy corroborates with the results presented here: it identified that the use of gastrostomy makes gain in weight possible, improves the quality of life of children and family members, and significantly reduces the number of admissions for respiratory infection ${ }^{(16)}$.

Clinical improvement of the child after installation of a technological device depends, however, on home care offered by the family members. According to the US literature, the period of adaptation of the parents to the therapeutic regime after the transition of a child submitted to a tracheostomy can be a factor that influences the number of re-admissions. To the extent that the family members gain experience of daily care of the child and develop the necessary skills for the care of this device, re-admissions can become less frequent ${ }^{(11)}$. 
The variable number of drugs used by the children of the present study represented a risk for the outcome. In the population of this study, use of drugs, although it also aims to improve clinical condition, in fact was associated with increase in the number of involuntary hospital admissions.

This is in line with the result of a study in the United States which aimed to characterize healthcare actions in relation to adverse events due to use of drugs in children with complex chronic conditions, determine which drugs were associated with adverse events, and identify whether the adverse events resulted in a higher probability of hospitalization for children with complex chronic conditions than for those without complex chronic conditions. The study concluded that children with complex chronic conditions presented a greater risk than other children of needing medical care and hospitalization due to the adverse events of the drugs used. Among the drugs with the highest levels of adverse events were the psychotropics, the antimicrobials, the anticonvulsants, hormones/steroids and analgesics. Finally, the authors stated that little is known about the negative consequences of the use of these drugs in this client group, and that further studies are needed to understand the mechanisms that cause the increase in the risk of adverse events in the children with complex chronic conditions ${ }^{(17)}$.

Another point of view dealt with in the international literature refers to errors in the administration of the drugs in the context of a complex therapy regimen. On this point, one study sought to describe the frequency of errors in administration of anticonvulsants among children with epilepsy admitted to hospital for reasons not related to convulsions, and described the factors associated with the occurrence of errors. The results show that $24 \%$ of the participating children had experience with errors of administration of anticonvulsants, the most common error being non-administration of the drug due to forgetting, and errors related to the dosage. Frequency of administration of anticonvulsants, and change in the carer responsible, were the factors most strongly associated with the chance of errors ${ }^{(18)}$.

\section{CONCLUSION}

The results presented provide input information for planning of care for technology-dependent children, by identifying the factors associated with involuntary hospital admissions in this client group. Having knowledge of the risk and protection factors that are associated with hospital admissions, it is possible to propose new preventive strategies that will certainly provide a reduction in the number of admissions, and a consequent reduction in clinical deterioration and family misadjustments.

Starting from the point of view that the nursing team has a fundamental role in the handling of the therapeutic regime of these children, it is recommended that there should be effective participation in the process of transition to home and subsequent accompaniment, with priority attention for children of younger age undergoing a complex therapy regimen, especially in the use of drug therapy. Although the number of technological devices has been considered as a protection factor, implementation of education actions relating to the specific handling and care of each device also becomes necessary.

Although the results of this study find support in the literature and in the clinical experience of the investigators, it is relevant to point out some limitations. The main one relates to its being a cross-sectional study, which prevents it being possible to identify relations of cause and effect. Thus, although the effect of risk and protection is assumed, based on the associations observed, it is not possible to establish a causal relationship between the factors analyzed and involuntary hospital admissions. Also, the data were collected based on self-report by the mother or guardian, remembering the past, making the results subject to reverse causality bias and memory bias. These limitations, however, do not invalidate the results of the survey, but indicate the need for future studies, with a longitudinal structure and greater accuracy of the information collected.

\section{RESUMO}

Objetivo: Identificar os fatores associados à hospitalização não eletiva em crianças dependentes de tecnologia, no município de Ribeirão Preto-SP. Método: Estudo transversal, com abordagem quantitativa. Após busca ativa, foram identificadas 124 crianças que se enquadravam nos critérios de inclusão, ou seja, crianças entre 0 e 12 anos de idade. Os dados foram coletados durante visita domiciliária com mães ou responsáveis pelas crianças, por meio da aplicação de um questionário. A análise dos dados seguiu os pressupostos da técnica de Modelos Lineares Generalizados. Resultados: Participaram do estudo 102 crianças dependentes de tecnologia, com idade entre 6 meses e 12 anos, das quais 57\% eram do sexo masculino. A média de internações não eletivas no último ano, entre as crianças estudadas, foi de $0,71( \pm 1,29)$. No modelo final, permaneceram significativamente associadas ao desfecho as seguintes variáveis: idade $(\mathrm{OR}=0,991 ; \mathrm{IC} 95 \%=0,985-0,997)$ e número de dispositivos $(\mathrm{OR}=0,387 ; \mathrm{IC} 95 \%=0,219-0,684)$, as quais se configuraram como fatores de proteção e quantidade de medicamentos $(\mathrm{OR}=1,532$; IC95\%=1,297-1,810), representando fator de risco para as internações não eletivas em crianças dependentes de tecnologia. Conclusão: Os resultados constituem-se em subsídio para se pensar o processo de cuidado às crianças dependentes de tecnologia ao fornecer um modelo explicativo para as internações não eletivas para esta clientela.

\section{DESCRITORES}

Criança; Hospitalização; Enfermagem Pediátrica.

\section{RESUMEN}

Objetivo: Identificar los factores asociados con la hospitalización no electiva en niños dependientes de tecnología, en el municipio de Ribeirão Preto-SP. Método: Estudio transversal, con abordaje cuantitativo. Después de búsqueda activa, fueron identificados 124 niños que se encuadraban en los criterios de inclusión, es decir, niños entre 0 y 12 años de edad. Los datos fueron recogidos durante visita domiciliaria con madres o responsables por los niños, mediante aplicación de un cuestionario. El análisis de los datos siguió los 
supuestos de la técnica de Modelos Lineales Generalizados. Resultados: Participaron del estudio 102 niños dependientes de tecnología, con edad entre 6 meses y 12 años, de los que el 57\% eran del sexo masculino. El promedio de ingresos hospitalarios no electivos el último año, entre los niños estudiados, fue de $0,71( \pm 1,29)$. En el modelo final, permanecieron significativamente asociadas al resultado las siguientes variables: edad $(\mathrm{OR}=0,991 ; \mathrm{IC} 95 \%=0,985-0,997)$ y número de dispositivos $(\mathrm{OR}=0,387 ; \mathrm{IC} 95 \%=0,219-0,684)$, las que se configuraron como factores de protección y cantidad de fármacos $(\mathrm{OR}=1,532 ; \mathrm{IC} 95 \%=1,297-1,810)$, representando factor de riesgo para las hospitalizaciones no electivas en niños dependientes de tecnología. Conclusión: Los resultados se constituyen en subsidio para pensarse el proceso de cuidados a los niños dependientes de tecnología al suministrar un modelo explicativo para los ingresos hospitalarios no electivos para esa clientela.

\section{DESCRIPTORES}

Niño; Hospitalización; Enfermería Pediátrica.

\section{REFERENCES}

1. Mesman GR, Kuo DZ, Carroll JL, Ward WL. The impact of technology dependence on children and their families. J Pediatr Health Care. $2013 ; 27(6): 451-9$

2. Kuhlthau KA, Bloom S, Van Cleave J, Knapp AA, Romm D, Klatka K, et al. Evidence for family-centered care for children with special health care needs: a systematic review. Acad Pediatr. 2011;11(2):136-43.

3. Buescher PA, Whitmire JT, Brunssen S, Kluttz-Hile CE. Children who are medically fragile in North Carolina: using medicaid data to estimate prevalence and medical care costs in 2004. Matern Child Health J. 2006;10(5):461-6.

4. Cohen E, Kuo DZ, Agrawal R, Berry JG, Bhagat SK, Simon TD, et al. Children with medical complexity: an emerging population for clinical and research initiatives. Pediatrics. 2011;127(3):529-38.

5. Bethell CD, Newacheck PW, Fine A, Strickland BB, Antonelli RC, Wilhelm CL, et al. Optimizing health and health care systems for children with special health care needs using the life course perspective. Matern Child Health J. 2014;18(2):467-77.

6. Neves ET, Cabral IE, Silveira A. Family network of children with special health needs: implications for Nursing. Rev Latino Am Enfermagem. 2013;21(2):562-70.

7. Hudson SM. Hospital readmissions and repeat emergency department visits among children with medical complexity: an integrative review. J Pediatr Nurs. 2013;28 (4):316-39.

8. Moraes JRMM, Cabral IE. The social network of children with special healthcare needs in the (in)visibility of nursing care. Rev Latino Am Enfermagem. 2012;20(2): 282-8.

9. Elias ER, Murphy NA. Home care of children and youth with complex health care needs and technology dependencies. Pediatrics. 2012;129(5):996-1005.

10. Okido ACC, Pizzinacco TMP, Furtado MCC, Lima RAG. Technology-dependent children: the maternal care experience. Rev Esc Enferm USP. 2012;46(5):1065-72.

11. Brittan MS, Sills MR, Fox D, Campagna EJ, Shmueli D, Feinstein JA, et al. Outpatient follow-up visits and readmission in medically complex children enrolled in Medicaid. J Pediatr. 2015;166(4):998-1005

12. Fisher LD, Belle GV. Biostatistics: a methodology for the health sciences. New York: John Wiley \& Sons; 1993.

13. Paula GA. Modelos de regressão: com apoio computacional. São Paulo: IME-USP; 2004.

14. Neuman MI, Hall M, Gay JC, Blaschke AJ, Williams DJ, Parikh K, et al. Readmissions among children previously hospitalized with pneumonia. Pediatrics. 2014;134(1):100-9.

15. Berry JG, Graham DA, Graham RJ, Zhou J, Putney HL, O'Brien JE, et al. Predictors of clinical outcomes and hospital resource use of children after tracheotomy. Pediatrics. 2009;124(2):563-72.

16. Sullivan PB, Morrice JS, Vernon-Roberts A, Grant H, Eltumi M, Thomas AG. Does gastrostomy tube feeding in children with cerebral palsy increase the risk of respiratory morbidity? Arch Dis Child. 2006;91(6):478-82.

17. Feinstein JA, Feudtner C, Kempe A. Adverse drug event-related emergency department visits associated with complex chronic conditions. Pediatrics. 2014;133 (6):e1575-85.

18. Jones C, Missanelli M, Dure L, Funkhouser E, Kaffka J, Kilgore M, et al. Anticonvulsant medication errors in children with epilepsy during the home-to-hospital transition. J Child Neurol. 2013;28(3):314-20. 